\title{
KLUCZOWE KOMPETENCJE NA STANOWISKU LEŚNICZEGO NA PRZYKŁADZIE NADLEŚNICTWA ZAPOROWO
}

Z a r y s t r e ś c i: We wstępie artykułu określono znaczenie podjętego tematu dla praktyki zarządzania. W rozdziale pierwszym dokonano przeglądu literatury w celu omówienia teoretycznych aspektów kompetencji. Następnie scharakteryzowano Nadleśnictwo Zaporowo, gdzie wśród leśniczych przeprowadzono badania ankietowe. Celem badania była próba ustalenia, które z kluczowych kompetencji posiadają pracownicy zatrudnieni na stanowisku leśniczego. Natomiast w kolejnym rozdziale omówiono metodykę postępowania badawczego i przedstawiono wyniki badań. Wnioski wynikające z analizy wyników przedstawiono w zakończeniu.

S ł o w a k 1 u c z o w e: kluczowe kompetencje; leśniczy; nadleśnictwo.

\section{WSTĘP}

Kluczowe kompetencje w postaci wiedzy, umiejętności i postaw odpowiednich do każdej sytuacji mają podstawowe znaczenie dla każdego obywatela społeczeństwa opartego na wiedzy. Zapewniają wartość dodaną rynkowi pracy, spójność społeczną i aktywne obywatelstwo, oferując elastyczność i zdolność adaptacji, satysfakcję i motywację. Parlament Europejski i Rada zalecają państwom członkowskim UE rozwijanie

* Adres do korespondencji: Gabriela Roszyk-Kowalska, Uniwersytet Ekonomiczny w Poznaniu, Wydział Zarządzania, Katedra Teorii Organizacji i Zarządzania, al. Niepodległości 10, 61-875 Poznań, e-mail: g.roszyk-kowalska@ue.poznan.pl 
kompetencji kluczowych u wszystkich obywateli w procesie uczenia się przez całe życie. Kluczowe kompetencje są szczególnie niezbędne do samorealizacji i rozwoju osobistego, integracji społecznej, bycia aktywnym obywatelem i zatrudnienia.

Kompetencje kluczowe mają istotne znaczenie w społeczeństwie wiedzy i gwarantują większą elastyczność siły roboczej, umożliwiając jej szybsze dostosowanie się do stałych zmian w świecie, w którym zachodzą coraz liczniejsze wzajemne powiązania. Stanowią również ważny czynnik innowacji, produktywności i konkurencyjności, a ponadto mają wpływ na motywację i zadowolenie pracowników oraz jakość pracy.

Osoby, które powinny nabyć kluczowe kompetencje, to zarówno młodzi ludzie (kończący obowiązkową edukację i szkolenia przygotowujące ich do dorosłego życia, zwłaszcza do życia zawodowego, a jednocześnie tworzące podstawy do dalszej nauki), jak i osoby dorosłe.

Zdobywanie kluczowych kompetencji jest spójne z zasadami równości i dostępu dla wszystkich. Niniejsze ramy odniesienia dotyczą również grup znajdujących się w niekorzystnej sytuacji, których potencjał edukacyjny wymaga wsparcia (na przykład osoby o niskich kwalifikacjach podstawowych, osoby przedwcześnie kończące naukę szkolną, osoby niepełnosprawne, migranci itp.).

Nadleśnictwo Zaporowo jest jedną z 430 podstawowych jednostek Państwowego Gospodarstwa Leśnego Lasy Państwowe. W Nadleśnictwie zatrudnionych jest 60 osób, w tym 15 na stanowisku leśniczego. Leśniczy to najniższe w organizacji stanowisko kierownicze, które prowadzi gospodarkę leśną w leśnictwie i podlega bezpośrednio zastępcy nadleśniczego.

Celem artykułu jest próba ustalenia, które z kluczowych kompetencji posiadają pracownicy zatrudnieni na stanowisku leśniczego oraz które z tych kompetencji są im najbardziej potrzebne. Na przykładzie Nadleśnictwa Zaporowo podjęto próbę ustalenia, które z kluczowych kompetencji występują na tym stanowisku i w jakim stopniu zostały opanowane.

\section{CHARAKTERYSTYKA KLUCZOWYCH KOMPETENCJI}

Kompetencje ogólnie mogą być rozumiane jako ogół wiedzy, umiejętności i postaw. Umiejętności są to zdolności, które powinien posiadać kierownik dla sprawnego i skutecznego osiągania celów z zakresu organizacji i zarządzania podmiotami gospodarczymi, czy szerzej organiza- 
cjami [Nogalski, Śniadecki, 2001, s. 151]. Odmienność definicji pojęcia kompetencji spotykana w literaturze przedmiotu utrudnia zaprezentowanie uniwersalnej definicji, gdyż kompetencje mają charakter zarówno specyficzny, jak i ogólny. Specyficzny charakter kompetencji związany jest $\mathrm{z}$ zadaniami zawodowymi, konkretnym miejscem i stanowiskiem pracy. Natomiast ogólny charakter kompetencji związany jest z szeroko rozumianymi kompetencjami społecznymi, przejawiającymi się w różnych zadaniach i obszarach działania. Do grupy kompetencji ogólnych zalicza się te, które są powszechnie wykorzystywane na (potencjalnie) wszystkich stanowiskach w organizacji [Czapla, 2011].

W zaleceniach Parlamentu Europejskiego i Rady Unii Europejskiej z 18 grudnia 2006 r. w sprawie kompetencji kluczowych w procesie uczenia się przez całe życie (2006/962/WE) Parlament Europejski i Rada zalecają państwom członkowskim UE rozwijanie kompetencji kluczowych u wszystkich, w ramach ich strategii uczenia się przez całe życie [Gawrońska, 2013]. Kluczowe kompetencje są definiowane w tym dokumencie jako połączenie wiedzy, umiejętności i postaw odpowiednich do sytuacji. Kluczowe kompetencje to te, których wszystkie osoby potrzebują do samorealizacji i rozwoju osobistego, integracji społecznej i zatrudnienia oraz bycia aktywnym obywatelem.

W ramach odniesienia ustalono osiem takich kluczowych kompetencji. Zaliczamy do nich: porozumiewanie się w języku ojczystym, porozumiewanie się w językach obcych, kompetencje matematyczne i podstawowe kompetencje naukowo-techniczne, kompetencje informatyczne, umiejętność uczenia się, kompetencje społeczne i obywatelskie, poczucie inicjatywy i przedsiębiorczość oraz świadomość i ekspresja kulturowa.

Wyróżnionym kluczowym kompetencjom należy nadać jedną wagę, ponieważ każda z nich może przyczynić się do „udanego” życia w społeczeństwie. Zakresy wielu spośród tych kompetencji częściowo się pokrywają i są powiązane [Roszyk-Kowalska, 2014].

W większości krajów wprowadzono w życie takie programy, które realizowałyby kształtowanie tych kompetencji. Znalazło to również wyraz w polskiej reformie oświaty. Przy opracowywaniu projektu nowej podstawy programowej, ogłoszonej w Rozporządzeniu Ministra Edukacji Narodowej z 23 grudnia 2008 r. w sprawie podstawy programowej wychowywania przedszkolnego oraz kształcenia ogólnego w poszczególnych typach szkół, uwzględniono także Zalecenie Parlamentu Europejskiego i Rady z 18 grudnia 2006 r. w sprawie kluczowych kompetencji w procesie uczenia się przez całe życie. 
Kluczowe kompetencje odgrywają szczególną rolę w procesie uczenia się, są istotne do osiągania przez człowieka celów społecznych oraz są potrzebne na większości stanowisk pracy.

\section{CHARAKTERYSTYKA NADLEŚNICTWA ZAPOROWO}

Nadleśnictwo Zaporowo położone jest w północnej części kraju, na terenie województwa warmińsko-mazurskiego. Swoim zasięgiem przylega do granicy państwa oraz Zalewu Wiślanego (rysunek 1).

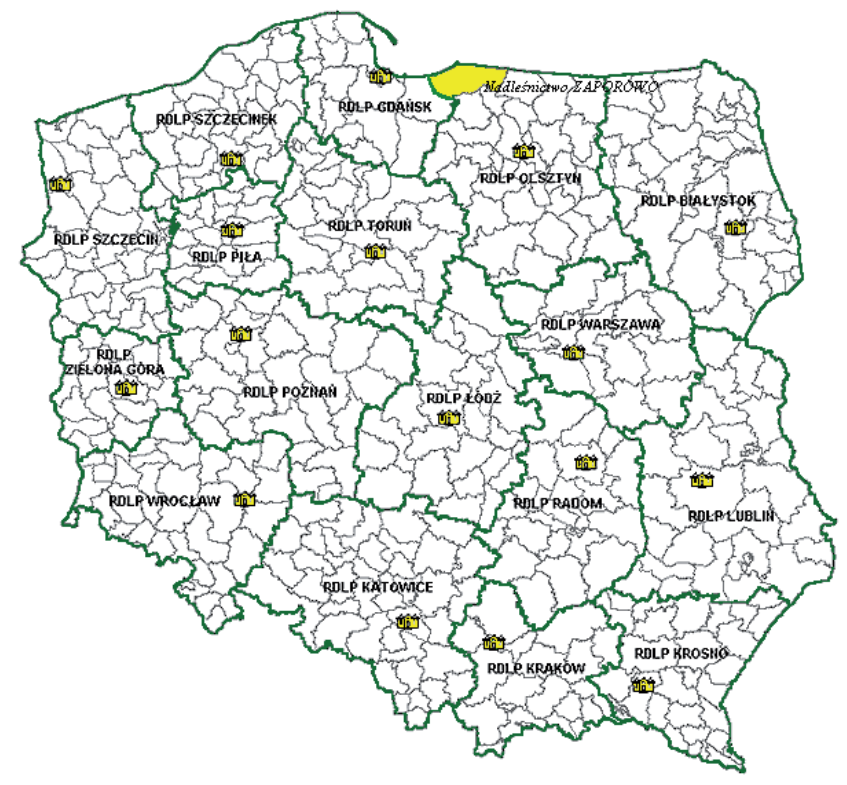

Rysunek 1. Położenie Nadleśnictwa Zaporowo na tle podziału Polski na Regionalne Dyrekcje Lasów Państwowych

Źródło: Archiwum Nadleśnictwa Zaporowo.

Nadleśnictwo Zaporowo jest jednym z trzydziestu trzech nadleśnictw wchodzących w skład Regionalnej Dyrekcji Lasów Państwowych w Olsztynie. Nadleśnictwo położone jest na terenie województwa warmińsko-mazurskiego. Łączna powierzchnia, którą zajmuje, wynosi 18291 ha i dzieli się na dwa obręby: Regity i Zaporowo. Nadleśnictwo podzielone jest na 14 leśnictw oraz leśnictwo szkółkarskie. 
Według regionalizacji przyrodniczo-leśnej lasy Nadleśnictwa Zaporowo leżą w Krainie I Bałtyckiej w Dzielnicy Elbląsko-Warmińskiej. Według podziału klimatycznego Okołowicza obszar ten znajduje się w dwóch regionach klimatycznych: północno-zachodnia część należy do regionu nadwiślańsko-żuławskiego, a pozostała do regionu mazurskiego. Średnia roczna ilość opadów wynosi $600-620 \mathrm{~mm}$, średnia temperatura wynosi: dla stycznia $-2,5^{\circ} \mathrm{C}$, lipca $17,4^{\circ} \mathrm{C}$, a roczna $7^{\circ} \mathrm{C}$. Okres wegetacyjny trwa na tym terenie 200-210 dni. Teren nadleśnictwa położony jest $\mathrm{w}$ dorzeczu rzek pobrzeża Bałtyku. Charakterystyczne dla tego obszaru jest ubóstwo jezior, rekompensowane gęstą siecią rzek i strumieni. Głównymi rzekami są tu Pasłęka, Bauda, Banówka i Narusa, a największym i w zasadzie jedynym zbiornikiem wodnym Jezioro Pierzchalskie.

Zasadnicza część Nadleśnictwa Zaporowo zajmuje płaski lub lekko falisty obszar i jest ograniczona od południowego zachodu Wzniesieniami Elbląskimi, od wschodu zaś Wzniesieniami Górowskimi.

\section{CHARAKTERYSTYKA STANOWISKA LEŚNICZEGO}

Leśniczy, zgodnie z ustawą o lasach, jest pracownikiem Służby Leśnej, czyli osobą, która: jest obywatelem polskim; ukończyła 21 lat; ma pełnie praw cywilnych i obywatelskich: posiada odpowiednie kwalifikacje zawodowe; cieszy się nienaganną opinią; zatrudniona jest w pełnym wymiarze pracy; posiada odpowiedni stan zdrowia oraz nie była karana sądownie za przestępstwo z chęci zysku lub z innych niskich pobudek [Ustawa o lasach, 1991].

Miejscem pracy leśniczego w Nadleśnictwie Zaporowo jest powierzone mu leśnictwo o powierzchni od 1042 do 1919 ha lasu.

Lasem w rozumieniu ustawy jest grunt o zwartej powierzchni co najmniej 0,10 ha, pokryty roślinnością leśną (uprawami leśnymi) - drzewami i krzewami oraz runem leśnym - lub przejściowo go pozbawiony (przeznaczony do produkcji leśnej lub stanowiący rezerwat przyrody lub wchodzący w skład parku narodowego albo wpisany do rejestru zabytków) oraz związany z gospodarka leśną, zajęty pod wykorzystywane dla potrzeb gospodarki leśnej: budynki i budowle, urządzenia melioracji wodnych, linie podziału przestrzennego lasu, drogi leśne, tereny pod liniami energetycznymi, szkółki leśne, miejsce składowania drewna, a także wykorzystywany na parkingi leśne i urządzenia turystyczne [Ustawa o lasach, 1991]. 
Jak wynika z wyżej wymienionej definicji lasu, miejsce pracy leśniczego jest bardzo różnorodne. Leśniczy pracuje w różnych warunkach klimatycznych na terenie otwartym. Warunki środowiska pracy są zmienne w zależności od konkretnego miejsca wykonywania prac. Może być to teren płaski, jak i górzysty, podmokły i suchy.

Do obowiązków leśniczego należy między innymi:

- ochrona granic leśnictwa, znaków granicznych i geodezyjnych, tablic ostrzegawczych i informacyjnych oraz ochrona lasu przed szkodnictwem ze strony człowieka,

- ciągła obserwacja, zbieranie i kompletowanie materiałów niezbędnych do opracowania prognoz zagrożenia drzewostanów przez czynniki bio- i abiotyczne, terminowe zwalczanie i zapobieganie szkodom przez nie wyrządzonym, otaczanie opieką pożytecznych ssaków, ptaków i owadów oraz stała troska o poprawę stanu sanitarnego drzewostanów,

- ciągła obserwacja stanu lasu oraz realizacja wynikających z niego potrzeb hodowlanych, polegających na prowadzeniu prac związanych ze zbiorem i przechowywaniem nasion i szyszek, zalesianiem, pielęgnowaniem lasu oraz melioracjami leśnymi,

- informowanie na bieżąco nadleśnictwa o niekorzystnych zjawiskach występujących w lasach,

- prowadzenie gospodarki łowieckiej w zakresie ustalonym przez nadleśniczego oraz wynikających z charakteru obwodu łowieckiego (wydzierżawiany lub pozostający pod zarządem nadleśnictwa),

- sporządzanie szacunków brakarskich, organizowanie i wyznaczanie cięć (zrębów, gniazd cięć częściowych i drzew do wyrębu w użytkach przedrębnych), drzew i drzewostanów do żywicowania, pozyskania kory garbarskiej i innych produktów leśnych oraz likwidacja skutków klęsk żywiołowych,

- dokonywanie, zgodnie z obowiązującymi normami, manipulacji, klasyfikacji i odbioru drewna oraz innych produktów leśnych z terenu leśnictwa oraz nadzór nad stanem drewna ściętego, wyrobionego i odebranego, a także z upoważnienia nadleśniczego prowadzenie sprzedaży drewna i użytków ubocznych,

- dokonywanie oceny podległych pracowników oraz przedkładanie propozycji ich zaszeregowania, awansowania i wyróżniania,

- podejmowanie działań w kierunku zabezpieczenia lasów, budynków, innych obiektów leśnych przed pożarami oraz nadzór nad przestrzeganiem przepisów dotyczących zabezpieczenia majątku leśnego 
przed pożarami przez podległych mu pracowników i osoby przebywające na terenach leśnych,

- kształtowanie właściwej atmosfery pracy oraz wyrabianie poczucia odpowiedzialności za wykonywanie zadań przez podległych pracowników,

- dbanie o utrzymanie właściwej estetyki osady leśnictwa oraz pomieszczenia kancelaryjnego.

Aby sprostać tym wszystkim obowiązkom, leśniczy musi posiadać kompetencje, gdyż poza wyżej wymienionymi zadaniami wypełnia również obowiązki administracyjno-reprezentacyjne. Należy do nich między innymi współpraca z instytucjami samorządowymi.

\section{METODYKA POSTĘPOWANIA BADAWCZEGO}

Celem badania była ocena kluczowych kompetencji osób zajmujących podstawowe stanowisko kierownicze w Państwowym Gospodarstwie Lasy Państwowe na przykładzie Nadleśnictwa Zaporowo. Argumentem przemawiającym za wyznaczeniem tego celu było podjęcie próby wskazania sposobów doskonalenia kompetencji przedsiębiorczych na najniższym, ale zarazem najważniejszym stanowisku w Lasach Państwowych. Celem praktycznym opracowania jest określenie wytycznych w zakresie doskonalenia kompetencji przedsiębiorczych w sektorze leśnym, ze szczególnym uwzględnieniem przedsiębiorstw zajmujących się gospodarką leśną. Teoretyczne rozważania literatury przedmiotu pozwoliły na sformułowanie hipotezy, która sprowadza się do stwierdzenia, że w Lasach Państwowych niezbędne jest posiadanie określonych kompetencji przedsiębiorczych i ich opanowanie na poziomie dobrym.

W badaniach przyjęto skalę ocen opanowanych kompetencji od 2 do 5, co oznacza: 2 - niedostatecznie, 3 - dostatecznie, 4 - dobrze oraz 5 bardzo dobrze. Za przyjęciem tej skali przemawia fakt, że większość osób prowadzących działalność zna wymienione oceny (system ocen w szkolnictwie), gdyż na ich podstawie wartościowany był poziom wiedzy, kiedy byli uczniami i studentami (przeciętny wiek wyniósł nieco powyżej 48 lat, najmłodszy leśniczy miał 37 lat, a najstarszy 59) (wykres 1). 


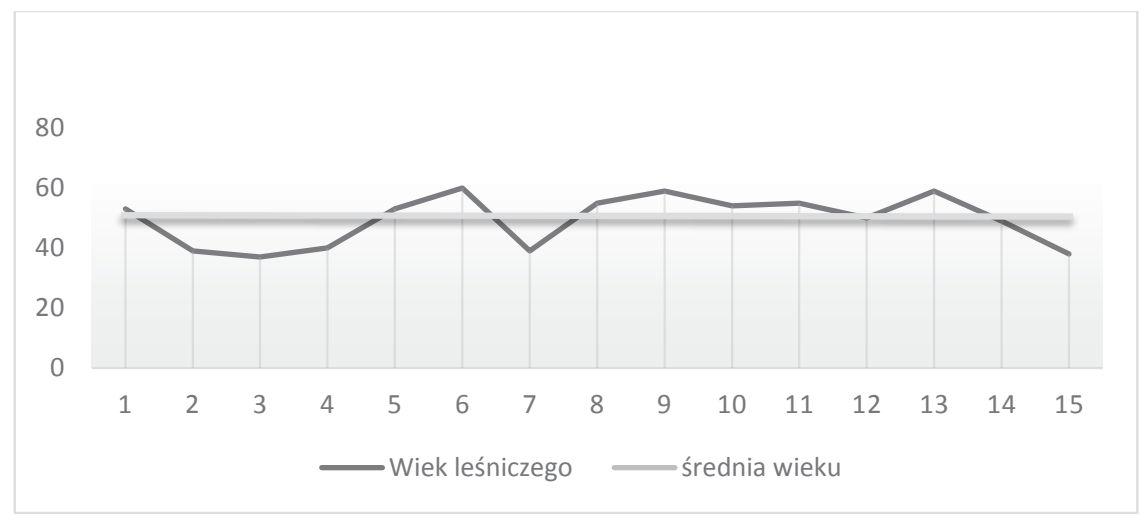

Wykres. 1. Wiek leśniczych zatrudnionych w Nadleśnictwie Zaporowo Źródło: opracowanie własne.

Badania przeprowadzono przy zastosowaniu procedury diagnostycznej. Przyjęto ją, aby ustalić istniejący aktualnie stan rzeczy. Podstawą wyznaczenia wielkości była liczba uzyskanych ankiet zwrotnych. Uzyskano 15 ankiet, które zostały wypełnione poprawnie i kompletnie, co stanowiło $100 \%$ całej populacji leśniczych Nadleśnictwa Zaporowo. Na ich podstawie dokonano analizy kluczowych kompetencji osób pracujących na stanowisku leśniczego.

\section{ANALIZA KLUCZOWYCH KOMPETENCJI NA STANOWISKU LEŚNICZEGO}

Leśniczowie zatrudnieni w Nadleśnictwie Zaporowo, biorący udział w badaniach, to mężczyźni posiadający w $67 \%$ wyższe wykształcenie, a $23 \%$ wykształcenie techniczne (wykres 2). 


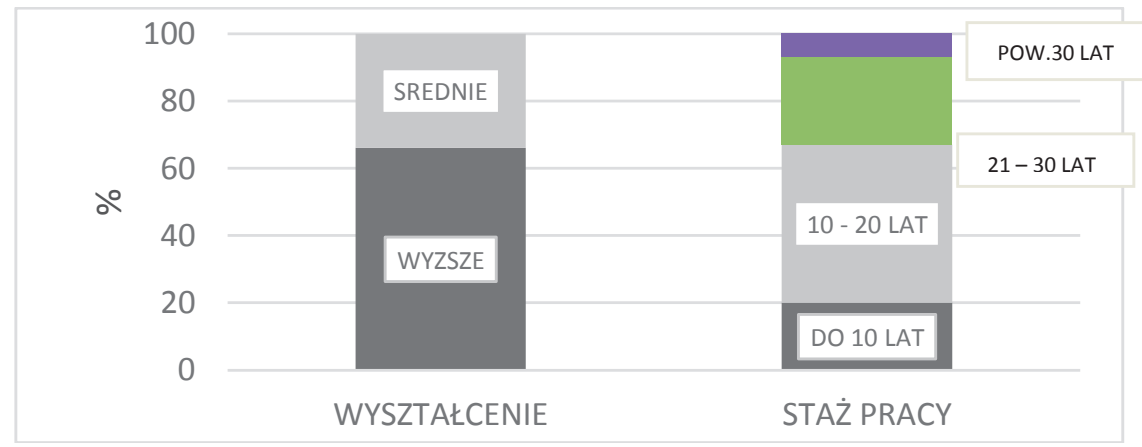

Wykres 2. Charakterystyka próbki badawczej - wykształcenie i staż pracy Źródło: opracowanie własne.

Jeżeli chodzi o poprawne porozumiewanie się w języku ojczystym, 93\% ankietowanych stwierdziło, że jest im potrzebne w pracy (wykres 3 ).

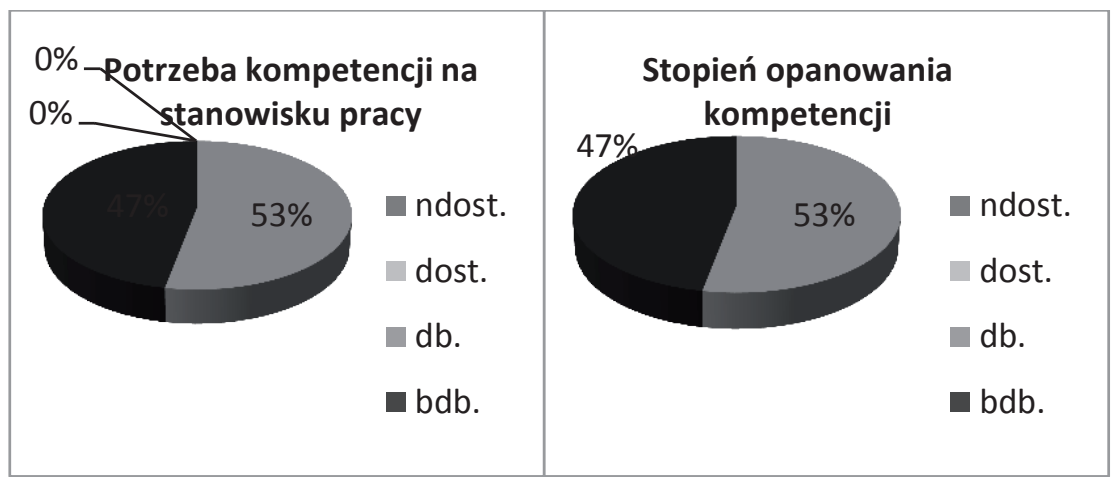

Wykres 3. Kompetencje porozumiewania się w języku ojczystym na stanowisku leśniczego

Źródło: opracowanie własne.

Wszyscy ankietowani opanowali język ojczysty na poziomie bardzo dobrym lub dobrym (wykres 3).

Znajomość języków obcych wśród ankietowanej kadry jest na poziomie zadowalającym. Zaledwie jedna osoba nie posługuje się żadnym językiem obcym. Dwoma i trzema językami obcymi posługuje się $47 \%$. Jednak tylko jedna spośród ankietowanych osób zadeklarowała znajomość języka 
obcego w stopniu bardzo dobrym, a aż 93\% w stopniu dostatecznym lub niedostatecznym (2 osoby) (wykres 4 ).

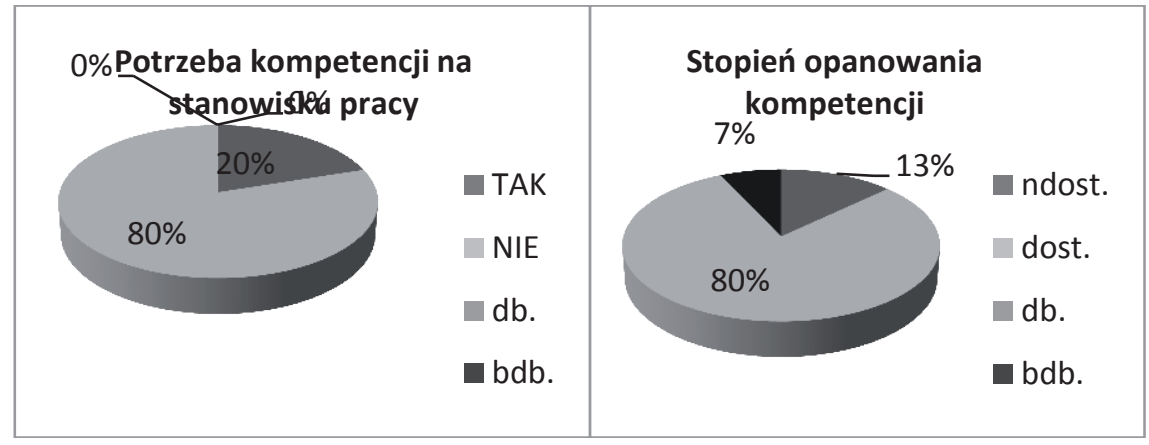

Wykres 4. Kompetencje porozumiewania się w języku obcym na stanowisku leśniczego

Źródło: opracowanie własne.

Kompetencje matematyczne i podstawowe naukowo-techniczne według ankietowanych potrzebne są na ich stanowisku pracy według 14 osób, a $73 \%$ z nich opanowało je w sposób dobry (60\%) i bardzo dobry (13\%) (wykres 5).

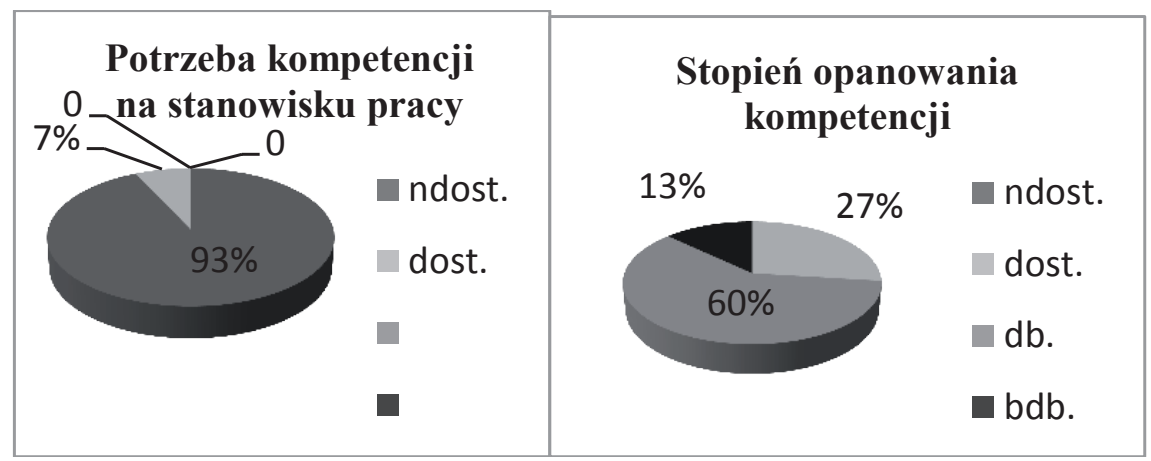

Wykres 5. Kompetencje matematyczne i naukowo-techniczne na stanowisku leśniczego

Źródło: opracowanie własne. 
Kompetencje informatyczne zdecydowana większość badanych (93\%) uznała za potrzebne na stanowisku leśniczego, z czego ponad połowa (53\%) opanowała je w sposób bardzo dobry i dobry (wykres 6).

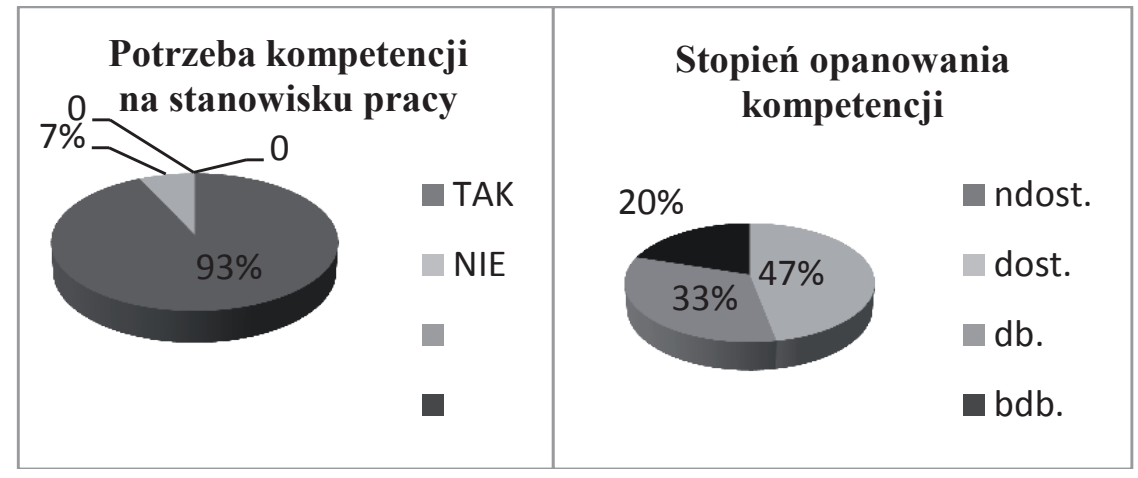

Wykres 6. Kompetencje informatyczne na stanowisku leśniczego

Źródło: opracowanie własne.

Aż 100\% ankietowanych uznało kompetencje uczenia się na stanowisku leśniczego za niezbędną (wykres 7).

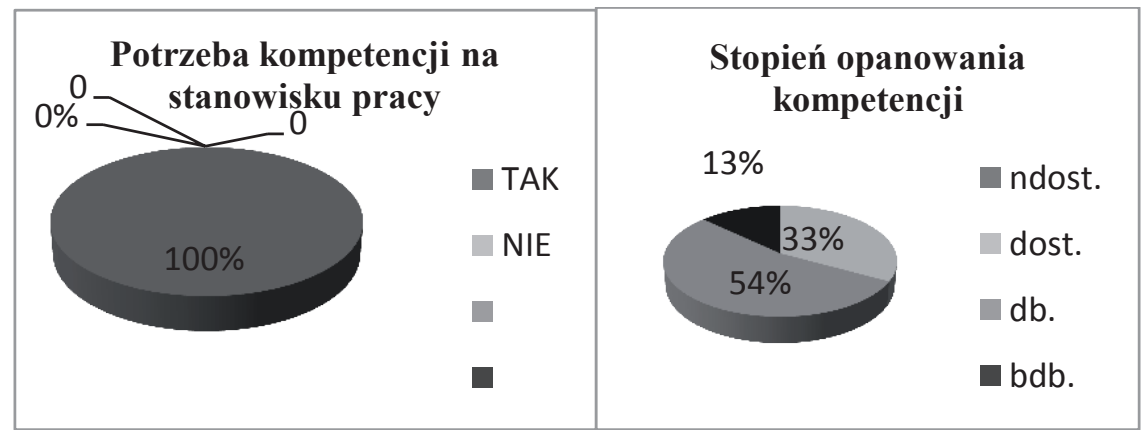

Wykres 7. Kompetencje uczenia się na stanowisku leśniczego

Źródło: opracowanie własne.

Także wszyscy ankietowani uznali za niezbędne kompetencje społeczne i obywatelskie na stanowisku leśniczego. Jednocześnie $80 \%$ leśniczych stwierdziła, że opanowali te kompetencje dobrze $(60 \%)$ i bardzo bobrze (20\%), a pozostali w sposób dostateczny (wykres 8). 


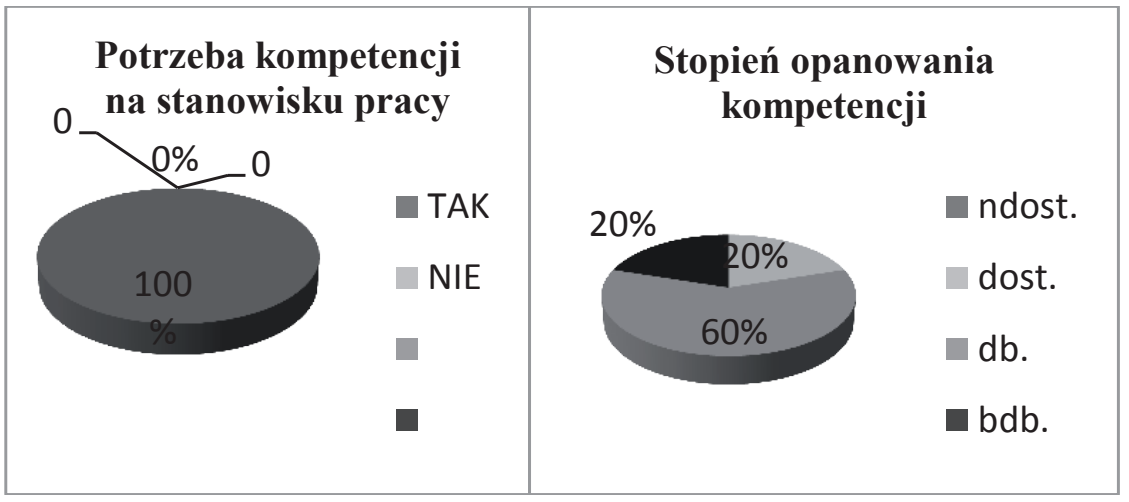

Wykres 8. Kompetencje społeczne i obywatelskie na stanowisku leśniczego Źródło: opracowanie własne.

Przeprowadzone badanie wykazało, że 100\% ankietowanych uważa kompetencje inicjatywy i przedsiębiorczości za niezbędne na swoim stanowisku pracy, a $47 \%$ opanowało je na poziomie dobrym (wykres 9).

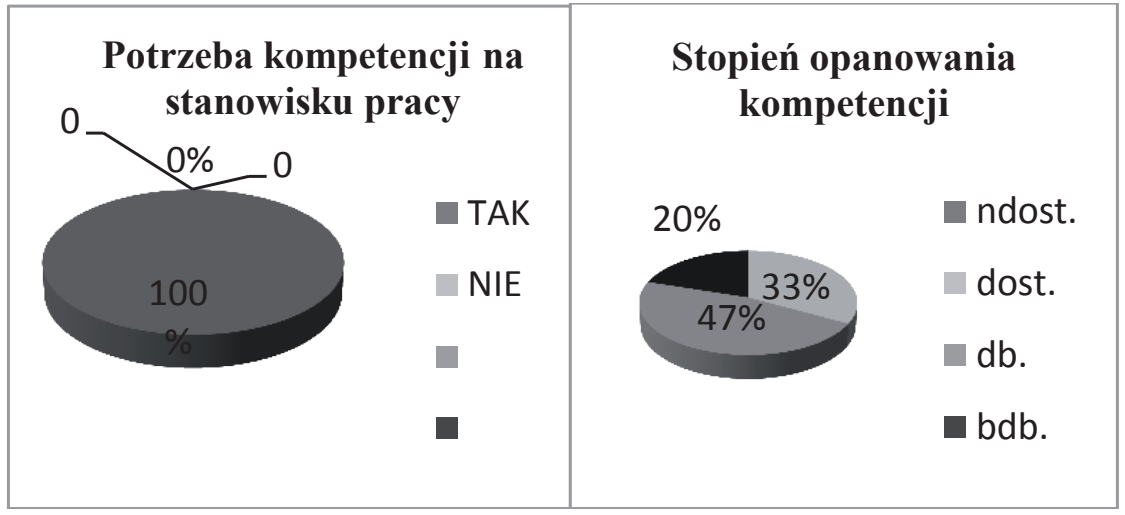

Wykres 9. Kompetencje inicjatywy i przedsiębiorczości na stanowisku leśniczego Źródło: opracowanie własne.

Zaledwie dwie osoby uważają kompetencje świadomości i ekspresji kulturalnej na stanowisku leśniczego za niepotrzebne, a jedna osoba uznała, że nie opanowała tej kompetencji (wykres 10). 


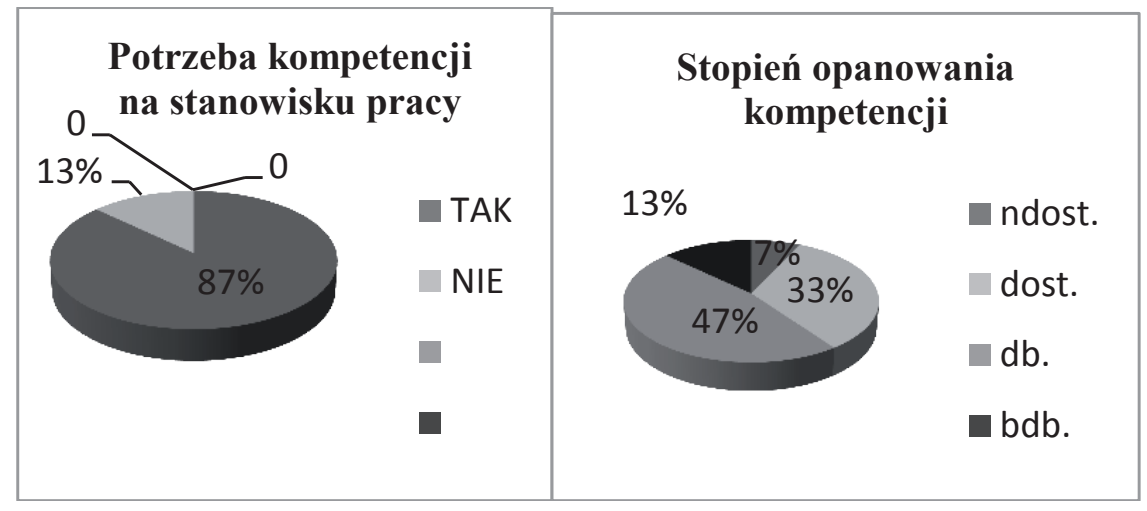

Wykres 10. Kompetencje świadomości i ekspresji kulturowej na stanowisku leśniczego

Źródło: opracowanie własne.

Analizując najwyżej i najniżej oceniane kompetencje, można sformułować wniosek, że kadra kierownicza za najbardziej potrzebne na stanowisku leśniczego uznała zdolność konsekwentnego uczenia się i organizowania własnego procesu uczenia, umiejętność dobrego współdziałania ze społeczeństwem oraz własną inicjatywę i przedsiębiorczość. Opanowanie na wysokim poziomie kompetencji współdziałania z innymi wymaga doskonalenia umiejętności panowania nad emocjami.

Nadleśnictwo Zaporowo, w którym pracuje ankietowana kadra, funkcjonuje już na rynku ponad 50 lat, a to powoduje legitymowanie się także umiejętnościami technicznymi, które mogą stanowić dla tej kadry źródło przewagi konkurencyjnej w samej organizacji.

Analizując poszczególne kompetencje leśniczych działających w sektorze leśnym, można sformułować wniosek, że średnio są one oceniane na poziomie dobrym (33-60\%), poza kompetencją opanowania języków obcych, gdzie większość ankietowanych (80\%) opanowała ją w sposób dostateczny. Jak wspomniano wyżej, posiadanie wszystkich kompetencji na poziomie bardzo dobrym może wywołać zjawisko wypalenia zawodowego. Dlatego też postuluje się, aby w samych przedsiębiorstwach doskonalić te kompetencje, które są najważniejsze, połączone bardzo silnie z umiejętnościami technicznymi, tak szczególnie ważnymi w sektorze leśnym.

Rozważając aplikacyjne walory doskonalenia kompetencji, należy podkreślić, że są one tym, czego się naucza i co zwiększa swoją wartość po okresie nauczania. Mechanizmy doskonalenia kompetencji istnieją po to, 
aby wnosić znaczący i wyróżniający się wkład w proces ich podnoszenia, tak ważny dla wszystkich nowoczesnych organizacji. Działanie kadry w organizacjach musi być widoczne poprzez pryzmat osiąganych celów w kategoriach doskonalonych kompetencji, szczególnie istotnych do osiągnięcia przez człowieka celów społecznych [Roszyk-Kowalska, 2014].

$\mathrm{Z}$ analizy wynika, że zaledwie jedna $\mathrm{z}$ ośmiu kluczowych kompetencji zalecanych przez UE (porozumiewania się w językach obcych) jest zbędna w pracy leśniczego, co świadczy, że branża leśna na podstawowym szczeblu zarządzania jest dość zamknięta na kontakty międzynarodowe.

\section{PODSUMOWANIE}

Rynek sektora leśnego zarówno w Polsce, jak i w całym globalnym świecie jest duży i ważny. Rozwój organizacji wynika z własnych potrzeb i inicjatywy firmy, ale również z rozwoju mającego źródło w nauce, potrzebach rynkowych, powiązaniach pomiędzy uczestnikami rynku, sieciach technologicznych czy społecznych [Żuber, 2008]. Determinują go zatem liczne uwarunkowania zewnętrzne oraz wewnętrzne. Wśród uwarunkowań wewnętrznych należy wymienić, jako jeden z kluczowych czynników, zasoby ludzkie, które powinny legitymować się zbiorem pożądanych kompetencji.

W opracowaniu wykazano, że pracownicy zatrudnieni na stanowisku leśniczego w Nadleśnictwie Zaporowo w większości opanowali wszystkie kluczowe kompetencje.

Wszyscy ankietowani uznali kompetencje uczenia się, społeczne i obywatelskie oraz poczucie inicjatywy i przedsiębiorczości za niezbędne w pracy leśniczego. Opanowanie większości kompetencji na poziomie dobrym świadczy o dużej świadomość ankietowanych oraz poczuciu własnej wartości. Jednocześnie stwarza to możliwość dalszego rozwoju pracowników, zwłaszcza kompetencji porozumiewania się obcym językiem, co w przyszłości może przyczynić się także do rozwoju samej organizacji, jaką są Lasy Państwowe. 


\section{LITERATURA}

Czapla T.P., (2011), Modelowanie kompetencji pracowniczych w organizacji, Wydawnictwo Uniwersytetu Łódzkiego, Łódź.

Kluczowe kompetencje dla uczenia się przez całe życie: Europejskie Ramy Odniesienia, 2006 http://skills4me.eu/index.php/pl/strona-glowna/projekt/pomysl-i-definicje-clc [10.04.2015].

Narzędzie do badania 11 kompetencji. Podręcznik użytkowania i instrukcja. Jestem przedsiębiorczy, Centrum Kompetencji - Grupa Szkoleniowo-Doradcza A. Gawrońska Sp. J., zespół merytoryczny projektu: I. Swiłło, L. Kisiel, M. Wojtkowiak, R. Posiadała oraz zespół partnera projektu Syntra West, Poznań 2013.

Nogalski B., Śniadecki J., (2001), Umiejętności menedżerskie w zarządzaniu przedsiębiorstwem, Oficyna Wydawnicza Ośrodka Postępu Organizacyjnego Sp. z o. o., Bydgoszcz.

Roszyk-Kowalska G., (2014), Przedsiębiorczość składowa kompetencji osób prowadzacych działalność - na przykladzie organizacji z branży high-trch [w:] P. Wachowiak, S. Winich (red.), Granice w zarzadzaniu kapitatem ludzkim, Oficyna Wydawnicza SGH w Warszawie, Warszawa.

Rozporządzenie Ministra Edukacji Narodowej z dnia 23 grudnia 2008 r. w sprawie podstawy programowej wychowania przedszkolnego oraz kształcenia ogólnego w poszczególnych typach szkół (Dz.U. 2009 nr 4 poz. 17).

Ustawa z dnia 28 września 1991 r. o lasach (Dz.U. 1991 nr 101 poz. 444).

Żuber R., (2008), Zarzadzanie rozwojem przedsiębiorstwa. Teoria i praktyka, Difin, Warszawa.

\section{KEY COMPETENCIES ON THE POSITION OF A FORESTMAN ON THE EXAMPLE OF ZAPOROWO FOREST DISTRICT}

A b stract: In the elaboration an attempt was made to analyse key competencies of a forest man. For this purpose, a questionnaire based on eight key competencies resulting from recommendations of the European Parliament and the Council of the European Union is developed. Key competencies include: communication in the mother tongue, communication in foreign languages, mathematical competencies and basic science and technology competencies, digital competencies, learning ability, social and civic competencies, sense of initiative, entrepreneurship, cultural awareness and expression. Surveys have been conducted among 
forest men in Zaporowo Forest District. On the basis of the data obtained, it has been concluded that mastery of most competencies at a good level testifies to large awareness and self-esteem of the respondents. At the same time, this offers the possibility of further development of employees, especially the development of their competencies concerning communication in a foreign language which in the future may contribute to the development of the organisation that is The State Forests National Forest Holding.

K e y w o r d s: key competencies; forest man; forest district. 